http://dx.doi.org/10.12775/szhf.2017.045

\author{
DARIUSZ PAKALSKI
}

Uniwersytet GdaŃski, GdAŃsk, Polska

e-mail: dariusz.pakalski@ug.edu.pl

\title{
Paradoks wdzięku. O teatrze marionetek Heinricha von Kleista
}

Pod datą 7 grudnia 1810 roku Kleist opublikował w Berliner Abendblätter krótką rozprawkę noszącą tytuł Von der Überlegung (O zastanowieniu). Kluczowy fragment tego tekstu przynosi radę, jaką przyszły syn pisarza miałby się kierować w kwestii myślenia i działania:

Powinieneś wiedzieć, że na zastanowienie dużo bardziej właściwy moment przypada po niż przed uczynkiem. Jeżeli wmiesza się ono w grę przed, lub w chwili decyzji, to zdaje się tylko tłumić, wstrzymywać i pętać siłę potrzebną do działania, jaka wypływa ze zdrowego uczucia. Natomiast można z niego uczynić użytek później, gdy działanie zostało zakończone, i właściwie po to dane jest ono człowiekowi, mianowicie aby uświadomił sobie, co w postepowaniu było błędne lub ułomne i wyregulował uczucie na przyszłość ${ }^{1}$.

Kilka dni później, w wydaniach Abendblätter datowanych od 12 do 15 grudnia 1810 roku, zamieszczone zostało (w czterech częściach) niewielkie dziełko Kleista $O$ teatrze marionetek, jeden z najbardziej intrygujących tekstów niemieckiej literatury. Badacze do dziś nie zakończyli sporu, czy

${ }^{1}$ H. von Kleist, Von der Überlegung, [w:] Werke und Briefe in vier Bänden, Bd. III, Sämtliche Erzählungen, Gedichte, Anekdoten, Schriften, Frankfurt a. M. 1986, s. 471. 
zakwalifikować je jako opowiadanie, studium czy traktat, czy też może jako zwykły felieton lub artykuł, parabolę, satyrę albo na przykład zapis zwykłej pogawędki. Hugo von Hofmannstahl wysunął nawet tezę, że od czasów Platońskich mitów nikt nie postarał się o tak „ujmujący myślą i wdziękiem znakomity kawałek filozofii” ${ }^{2}$, jak Kleist w swym Teatrze marionetek. Pozostając przy nawiązaniu do Platona, dziełko Kleista można również nazwać dialogiem wzbogaconym o elementy narracji, refleksji i fikcji.

Z obszaru narracyjnej fikcji pochodzi niewątpliwie opowiedziana w części czwartej tego intrygującego dialogu ${ }^{3}$ historia o fechtującym niedźwiedziu, mająca ścisły związek z cytowaną wyżej rozprawką O zastanowieniu. Zrelacjonujmy zatem za Kleistem to wydarzenie. Otóż pan C. - główny interlokutor dialogu - będąc w podróży po Rosji, znalazł się w posiadłości inflanckiego szlachcica pana von G. Synowie tego ostatniego, pomimo że ćwiczyli się $\mathrm{w}$ szermierce, nie byli $\mathrm{w}$ stanie $\mathrm{w}$ przyjacielskich pojedynkach pokonać gościa. Jako że każdy znajduje swojego mistrza, postanowili zaprowadzić go do niedźwiedzia, którego pan von G. posiadał w gospodarstwie. Niedźwiedź został przykuty do słupa i stanąwszy na tylnych łapach przyjął szermierczą postawę. Mocno zdziwiony pan C. natarł nań rapierem, niedźwiedź jednak uczynił „drobny ruch łapą” i odparował cios. Pan C. próbował go „zwodzić fintami”, jednak niedźwiedź na owe pozorowane ataki w ogóle nie reagował, natomiast wszystkie pchnięcia pomyślane poważnie parował bezbłędnie. Jak relacjonuje pan C. - „Z łapą uniesioną $\mathrm{w}$ pogotowiu stał przede mną oko w oko, jakby czytając w mojej duszy" [580n].

Czy anegdota o niedźwiedziu może zilustrować zjawisko wdzięku? Wydaje się, że jest od tego bardzo daleka. Jednak pan C. puentuje ją w sposób następujący: „Widzimy, że im bardziej w świecie organicznym mętnieje i słabnie refleksja, tym przemożniej i promienniej występuje wdzięk." [581] Oczywiście błędem byłoby rozumieć wypowiedź pana C. w taki sposób, że niedźwiedź paradoksalnie przewyższa człowieka pod względem wdzięku. Już chociażby ze względu na masę trudno przypisać temu zwierzęciu kojarzone z wdziękiem powab, lekkość i ujmującą powierzchowność czy też uważać za szczególnie wdzięczne ruchy jego łap. Traktując wniosek pana C. konsekwentnie,

${ }^{2}$ H. von Hofmannstahl, Deutsches Lesebuch, [w:] Gesammelte Werke in Einzelausgaben, Prosa IV, Frankfurt a. M. 1955, s. 138.

${ }^{3} \mathrm{~W}$ polskim przekładzie O teatrze marionetek Jakuba Ekiera w: Pisma teoretyczne niemieckich romantyków, opr. T. Namowicz, Wrocław-Warszawa-Kraków 2000, s. 571-581, podział na pierwotne „odcinki” nie został zaznaczony. Cytuję według tego wydania, podając strony w nawiasach kwadratowych. 
jeszcze więcej wdzięku należałoby poszukiwać na dalszych, niższych stopniach organicznego rozwoju, np. w żerujących w jakiejś padlinie robakach, a najwięcej w amebach. Opowiedziana przez Kleista historia stanowi jednak doskonałą parabolę fenomenu wdzięku. Dlaczego tak jest? Niedźwiedź swoje „drobne ruchy łapą" wykonuje bez najmniejszego zastanowienia, całkowicie bezwiednie i bezrefleksyjnie. Człowiek, niezależnie od tego, czy jako obserwator i badacz podejmuje refleksję nad naturą, czy tylko się jej przygląda, zawsze wchodzi z nią w relację podmiot - przedmiot. Niedźwiedź po prostu naturą jest. Nie daje się w pojedynku pokonać, ponieważ nie reaguje na finty, będące próbą wywiedzenia go w pole i zadania decydującego ciosu podstępem. Nie reaguje nie dlatego, że przejrzał je i zanalizował jako podstęp i kłamstwo, aby tym lepiej przygotować się na obronę ciosów prawdziwych. Coś takiego jak finty dla niedźwiedzia w ogóle nie istnieje. Prawda i rzeczywistość są dla niego tożsame i „tożsamość” z nimi determinuje jego działanie, dlatego właśnie na uderzenia prawdziwe reaguje on błyskawicznie i pewnie.

Niemiecki badacz Benno von Wiese, interpretując fragment o niedźwiedziu słusznie zwraca uwagę, że użyte tu przez Kleista sformułowanie: „jakby czytając w mojej duszy", jest sformułowaniem na wyrost i zakłada charakterystyczny dla ludzkiej świadomości rozdział na prawdę i fałsz ${ }^{4}$. Niedźwiedź nic nie czyni "jakby” i raczej nie „czyta” w duszy, lecz stoi z nią „oko w oko”. Wiedza niedźwiedzia jest wynikiem naocznego oglądu, oznacza bezpośredni wgląd w pewien stan rzeczy, jest niczym Spinozjańska scientia intuitiva, wiedza intuitywna, poznanie naoczne bez refleksji i bez rozumowego dowodu.

Poprzedzająca tę anegdotę część trzecia dialogu to pouczająca opowieść partnera pana von C. - odgrywającego tu rolę pierwszoosobowego autora tekstu - o młodzieńcu, „którego kształty roztaczały niezwykły urok” [579]. Zrelacjonujmy także i tę historię. Ów młodzieniec po wyjściu z kąpieli usiadł, chcąc sobie osuszyć stopę i spojrzał jednocześnie w lustro. W tym momencie zarówno on, jak i obecny przy tym autor opowiadania, spostrzegli zaskakujące podobieństwo figury młodzieńca do antycznej rzeźby chłopca wyciągającego cierń, jaką obaj mieli okazję oglądać niedługo przedtem w muzeum w Paryżu. Była to chwila decydująca, w której - jak czytamy w tekście - „młodzieniec przez jedno błahe spojrzenie [...] utracił niewinność, i, pomimo wszelkich możliwych starań nie odnalazł jej już nigdy" [578]. Obaj uświa-

${ }^{4}$ B. von Wiese, Das verlorene und wieder zu findende Paradies. Eine Studie über den Begriff der Anmut bei Goethe, Kleist und Schiller, w: Kleists Aufsatz über das Marionettentheater, hrsg. H. Sembdner, Berlin 1967, s. 204. 
domili sobie naturalny wdzięk jego postaci. Jednak podjęta - najwidoczniej z próżności - próba uzyskania „pewności wdzięku” zakończyła się całkowitą klęską. Młodzieniec uniósł stopę po raz drugi, trzeci i dziesiąty, nie mógł jednak wykonać takiego samego ruchu jak przedtem. Co więcej, jego ruchy stawały się coraz bardziej wymuszone i komiczne, a obserwator $\mathrm{z}$ trudem musiał tłumić śmiech. Odtąd ów młody człowiek całe dnie spędzał przed lustrem, chcąc na próżno odzyskać utracony wdzięk. Nieszczęście młodzieńca polegało na tym, że gdy tylko uzyskał świadomość własnego wdzięku, już go utracił. Wszystkie ruchy, jakie wykonywał, były już z góry skażone przez świadomy zamiar i to własna jego świadomość zabiła wdzięk.

W tym miejscu zbliżamy się do opisu tytułowego teatru marionetek, zawartego w dwóch pierwszych częściach dialogu. Jak stwierdza Kleist, najwięcej wdzięku posiada istota, która w ogóle nie ma świadomości - marionetka, mechaniczna kukła poruszana przez animatora. Pomyłki młodzieńca były wynikiem ruchów determinowanych przez umysł, natomiast jak celnie stwierdza narrator, „umysł nie może mylić się tam, gdzie nie istnieje” [577]. Marionetki prezentują niezwykły rytm ruchów i stanowią niedościgły wzór dla tancerzy. Wcale nie potrzeba, by animator sterował dziesiątkami nici, każdy ruch posiada swój „środek ciężkości”, wystarczy więc zapanować tylko nad tym ostatnim, a wszystkie członki marionetki z osobna, będąc jedynie wahadłami, „same ruszą za nim”. Linia, jaką zakreśla środek ciężkości marionetki, to w większości przypadków linia prosta, jednak także elipsa - naturalny kształt ruchu członków ludzkiego ciała - nie wymaga od animatora większego kunsztu. Proporcja, lekkość, wreszcie wdzięk marionetki, są wyższe aniżeli u żywego tancerza, ponieważ jej ruch powstaje wyłącznie w sposób niewymuszony, na zasadzie wahadła. Tancerz nie ma takiej władzy nad własnym środkiem ciężkości, jaką posiada nad nim w stosunku do marionetki animator. Koronnym argumentem na rzecz przewagi, jaką marionetka posiada w ruchu nad żywym tancerzem jest to, że „ona by się nigdy nie krygowała” [576]. „Krygowanie się bowiem - czytamy - powstaje wtedy, gdy dusza (vis motrix) znajduje się w innym punkcie niż środek ciężkości ruchu." [576]

Zatrzymajmy się na chwilę przy tym kluczowym fragmencie. Występujące w nim określenie duszy jako vis motrix (siła poruszająca) zasługuje na specjalną uwagę. Kleist odwołuje się tu do jednego z podstawowych pojęć metafizyki substancji cielesnej stosowanych przez Leibniza. W Nowym systemie... (Systéme Nouveau) znajduje się następujące zestawienie pojęć duszy i siły: „... we wszystkich gatunkach organicznych powinno być coś odpowia- 
dającego duszy, co [...] ja nazywam [...] siłą pierwotną"5. Według bliższej definicji wszczepiona pierwotna siła poruszająca (insita vis motrix primitiva) reprezentuje (nadaną w boskim akcie stworzenia) wewnętrzną aktywną siłę określającą naturę substancji w ogóle. Każda substancja działa bez przerwy, nie wyłączając ciała, w którym nigdy nie spotyka się absolutnego spoczynku. Jeżeli siła ta połączona jest z rzeczywistym ruchem, określa się ją siłą żywą. Vis motrix i dusza oznaczają tym samym zasadę ożywiającą substancje cielesne. Takie pojęcie siły jako pewnej energii, którą posiada nasze ciało, jest przeciwstawne sile ciążenia Newtona.

Jak wynika $\mathrm{z}$ opisu przedstawionego przez Kleista w ruchu marionetki, zrównoważone zostają te dwie siły. Działanie przyrównanej do duszy siły poruszającej niweluje działanie siły ciążenia, tak że obie wydają się zespalać w jedną. $\mathrm{O}$ wdzięku ruchów marionetki decyduje zatem zapanowanie siły poruszającej nad siłą ciążenia, albo przynajmniej takie przeciwstawienie się jej, że nie uzyskuje ona przewagi. Własnością marionetek jest „antygrawitacja” [577]. Lalki dotykają ziemi tylko po to, aby ją "musnąć” i „ożywić polot ciała", żywy tancerz natomiast nie może całkowicie opanować własnej masy i siły ciążenia skierowanej ku ziemi i musi na niej oprzeć całe swe ciało. Jak z sarkazmem ocenia w dialogu pan C. wysiłki pewnej tancerki: „ileż by dała nasza poczciwa pani G. za to, by być lżejszą o sześćdziesiąt funtów" [577]. Inne empiryczne przykłady wzięte ze sceny także dotyczą rozdźwięku pomiędzy vis motrix i vis gravitas, jaki bardzo trudno jest rzeczywistym tancerzom przezwyciężyć. Układ środków ciężkości w ruchu marionetki jest jednak zdecydowanie „bliższy naturze” [576]. Na dowód wystarczy tylko spojrzeć na panią P. - opowiada dalej pan C. - grającą Dafne ściganą przez Apollina; „tancerka gibie się, jakby miała się złamać”, a jej dusza tkwi gdzieś „w kręgach krzyża” [577]. Podobnie strach patrzeć na pana F. wręczającego jako Parys jabłko Wenerze - „dusza uwięzła mu w łokciu” [577]. Wniosek, jaki wysnuwa z powyższych przykładów: pan C. jest jednym z najważniejszych zdań dialogu. Błędów i pomyłek w kwestii wdzięku nie da się uniknąć „odkąd zjedliśmy owoc z drzewa poznania” [577]. Wtóruje mu zresztą narrator, dodając, że wie „wcale dobrze, jak bardzo świadomość burzy ludzki wdzięk" [578]. Poznanie własnego wdzięku sprawiło, że ów młodzieniec, bohater poprzedniej anegdoty, siłą woli próbował opanować siłę poruszającą i zastanawiał się, w którym punkcie ciała ją umieścić. Skończyło się to fia-

${ }^{5}$ G. W. Leibniz, Nowy system..., zarzuty..., uwagi... i odpowiedzi, przeł. S. Cichowicz, [w:] tenże, Pisma z metafizyki natury, wybór i red. S. Blandzi, Toruń 1999, s. 20. 
skiem i pozbawiło jego ruch naturalnego piękna. Podobnie owoc zjedzony z drzewa poznania powoduje krygowanie się tancerzy podczas tańca. Warto tu dodać, że wybrane przez tłumacza dialogu wychodzące $z$ użycia w języku polskim słowo „krygować się” jest odpowiednikiem niemieckiego „sich zieren”, co daje się przetłumaczyć także jako „robić ceregiele, ociągać się, wahać się, zachowywać się nienaturalnie”, a odpowiadający mu rzeczownik „Ziererei” jako „ceregiele, wymuszoność, przesada”. Poznanie i świadomość, czyli zastanawianie się nad wykonywanym ruchem (jak on ma wyglądać i jaki cel chcę nim osiągnąć) powodują, że zawsze pozostaje on czymś nienaturalnym, wymuszonym przez refleksję i zostaje zdemaskowany jako największy przeciwnik wdzięku. Taneczne ruchy marionetki - dodaje jeszcze pan C. - wykonywane są z takim „spokojem, lekkością i wdziękiem, jaki każdą myślącą głowę wprawi w osłupienie" [576]. Nie czujemy się zaskoczeni, że w innym miejscu, we wcześniejszym liście Kleista (z 31 sierpnia 1806 roku) pisanym z Królewca do bliskiego przyjaciela poety Augusta von Rühle, znajdujemy jasną deklarację na ten temat: „Każdy pierwszy ruch, wszystko, co żywiołowe, jest piękne - a staje się koślawe i dziwaczne, gdy tylko zaczyna być wyrozumowane. Ach, rozum! Ten nieszczęsny rozum!”

Kolejnym istotnym fragmentem prowadzonej przez obu panów dyskusji o lalkach jest wyjaśnienie wątpliwości dotyczących animatora. Oczywiste, że wczuwający się w środek ciężkości marionetki animator musi w jakiś sposób tańczyć. Czy zatem wdzięk marionetek nie jest jednak zasługą ludzką? Owszem, ale obaj rozmówcy zgodni są także co do tego, że jest zupełnie możliwe skonstruowanie odpowiedniej maszyny czy korby, za sprawą której ich taniec byłby wynikiem działania wyłącznie mechanicznych sił. Wówczas udałoby się z marionetek usunąć „to ostatnie rozdarcie ducha” [575], czyli jak trzeba te słowa zinterpretować, już do końca zlikwidować w ruchu podział na „myśleć’ i „być”. Najczystszy wdzięk ukazuje się w istocie, która nie jest dotknięta takim podziałem, czyli jak stwierdza w jednym z końcowych zdań Kleist albo „nie mającej świadomości albo mającej świadomość nieskończoną czyli w kukle albo w bóstwie" [581]. Tu ponownie musimy się odwołać do niemieckiego oryginału, gdzie występuje w tym miejscu słowo „Gott” (nie „Gottheit”), Kleist ma na myśli po prostu Boga.

Autor Rozbitego dzbana nie jest oczywiście tym, który jako pierwszy wskazuje na ruch jako manifestację wdzięku. Mianem klasyka estetyki ruchu zo-

\footnotetext{
${ }^{6}$ Por. J. Piprek, J. Ippoldt, Wielki słownik niemiecko-polski, t. II, Warszawa 1983, s. 878.

${ }^{7}$ H. von Kleist, Listy, przeł. W. Markowska, Warszawa 1983, s. 422.
} 
stał określony Fryderyk Schiller, twórca słynnego studium $O$ wdzięku i godności (1793). Jednak ani w pismach teoretycznych Kleista, ani w jego listach nie znajdujemy śladu po lekturze tej rozprawy Schillera, w przeciwieństwie na przykład do licznych wzmianek na temat Kanta. Czy Kleist - intelektualista i pisarz - mógł treści głośnej i dyskutowanej wówczas rozprawy Schillera (odnosili się do niej na bieżąco i Kant i Goethe) nie znać? Mimo że nie pozostawił czy też, jak się wydaje, raczej nie chciał pozostawić dowodu, że ją szczegółowo studiował, już podstawowy motyw uwidocznienia się wdzięku w ruchu nie pozwala dialogu Kleista rozpatrywać inaczej niż jako swego rodzaju polemikę z Schillerem.

Porównując obie koncepcje, od razu trzeba wyodrębnić charakterystyczny punkt wspólny. Podobnie jak według Kleista, również zdaniem Schillera wdzięk objawia się najwyraźniej w postaci ruchów nieświadomych, w tej kwestii obaj pisarze są zgodni. Jak podkreśla weimarski klasyk „człowiek może w końcu dzięki kunsztowi i nauce" poddać wykonywane ruchy swojej woli

... i niby zręczny kuglarz - jak czytamy dalej - będzie umiał pokazać w mimicznym zwierciadle swej duszy taką postać, jaką tylko zechce, ale w takim człowieku wszystko będzie kłamstwem, a kunszt pochłonie całą jego naturę. Gracja natomiast zawsze musi wyrażać naturę, tj. musi być mimowolna (a przynajmniej taka się wydawać), sam zaś podmiot nie powinien stwarzać pozoru, że wie o swym wdzięku'

Schiller dokonuje również interesujących spostrzeżeń na temat „antygrawitacji”, pochodzą one jednak nie z rozprawy $O$ wdzięku i godności, lecz z powstałych niewiele wcześniej listów do drezdeńskiego przyjaciela Christiana Gottfrieda Körnera, wydanych później pod tytułem Kallias, czyli o pięknie. Siłę ciążenia, własność w opisie Kleista najbardziej przeciwną wdziękowi, określa Schiller tylko jako powszechne prawo przyrody ${ }^{9}$, które z zewnątrz determinuje naturalne formy przedmiotów czy ruchy istot żywych. Na przykład naturalna forma wazonu nie będzie zagrożona przez „obcą” siłę ciążenia,

${ }^{8}$ F. Schiller, O wdzięku igodności, [w:] tenże, Pisma teoretyczne, przeł. J. Prokopiuk, Warszawa 2011, s. 228. Pojęcia gracji i wdzięku traktuje Schiller, zgodnie z łacińskim źródłosłowem (gratia - wdzięk, powab), synonimicznie. W słowniku braci Grimm jedno ze znaczeń słowa gracja to ucieleśnienie pojęcia wdzięku (Jakob und Wilhelm Grimm, Deutsches Wörterbuch, http:// woerterbuchnetz.de/DWB (t. 8, szpalta 2246) [dostęp: 14.02.2017].

${ }^{9}$ F. Schiller, Kallias, czyli o pięknie, przeł. K. Kaśkiewicz, Kęty 2007, s. 56. 
jeżeli nie będzie się on kończył szerokim wybrzuszeniem, które po nalaniu wody i włożeniu kwiatów zagrażałoby jego stabilności. W takim przypadku siła ciążenia zapanowałaby nad jego formą. Podobnie ruch wynikający z natury jakiejś rzeczy może być piękny, natomiast ruch, który podlega masie i prawu ciążenia tę naturalność traci. Koń pociągowy porusza się z wysiłkiem, jego krok jest mozolny i ociężały, natomiast rączy rumak nigdy nie używa w ruchu więcej siły niż wymaga jego natura, biegnie tak lekko, „jak gdyby nic nie ważył" ${ }^{\prime \prime}$. W pierwszym przypadku masa opanowuje ruchy ciała zwierzęcia poruszającego się niezgrabnie i niezdarnie; tak samo - pisze Schiller - masa widoczna jest w budowie i ruchach słoni, niedźwiedzi (jak trzeba się domyślać, także tych fechtujących), byków itp. Odwrotnie ptak, niczym marionetka Kleista, jest naocznym dowodem, że masa i siła ciążenia opanowane zostały przez siłę poruszającą, czyli vis motrix z rozprawki Kleista. To właśnie dzięki tej „sile wewnętrznego życia”"11 ptak opiera się działaniu siły ciążenia. „Nie bez znaczenia zauważamy - dodaje Schiller - że taka wolność przezwyciężania ciężkości nierzadko używana jest jako symbol wolności”12.

Główną ideą, jaką wysuwa Schiller w rozprawie $O$ wdzięku i godności, jest uznanie praw natury wywierających wpływ na człowieka, choć można powiedzieć też odwrotnie, uznanie prawa człowieka do własnej natury. Rozprawa miała przynieść próbę mediacji pomiędzy skonfliktowanymi przez Kantowską etykę dziedzinami zmysłowości i rozumu, przyrody i wolności. Imperatywna forma prawa moralnego, zadająca przymus i ból człowiekowi, stanowi zdaniem Schillera widoczny uszczerbek tej etyki, jest środkiem zbyt drakońskim, na który człowiek nie zasługuje, poniża on bowiem i obraża ${ }^{13}$ zasadniczą część jego istoty. Nakazy moralne nie powinny szukać wroga w ludzkich uczuciach i w zmysłowości, lecz zaprzęgnąć je w służbę moralności, naturę należy uhonorować jako czynnik „współdziałający”. Inaczej nigdy nie uda się pokonać i obezwładnić pobudek z niej wypływających i będą one zawsze niczym Hydra podnosić głowę, natura nie uzna triumfu nad sobą, jeśli po prostu nie będzie mogła żyć.

W przeciwieństwie jednak do teorii o wdzięku marionetek głoszonej przez Kleista, w ujęciu Schillera wdziękiem charakteryzuje się tylko człowiek, re-

\footnotetext{
10 Tamże.

11 Tamże, s. 57.

12 Tamże.

${ }^{13}$ Por. tamże, s. 52. W przypadku etycznych aspektów takich cech jak godność czy wzniosłość Schiller w całości respektuje stanowisko Kanta. Por. chociażby F. Schiller, O wzniosłości, [w:] tenże, Pisma teoretyczne, s. 159-177.
} 
prezentant jednocześnie państwa natury i państwa wolności. Piękny lot ptaka czy rączy bieg rumaka stanowią, jak czytaliśmy wyżej, tylko symbol wolności. Schiller wdzięk i piękno rozumiał po Kantowsku, jako „wolność w zjawisku”, wyraz zdolności do samookreślania się $\mathrm{w}$ analogii do ustanawiającego prawa moralne rozumu. Stanowią one dla poety zmysłowy przykład, że „popędy natury łączą się harmonijnie z prawami rozumu”"14, że człowiek nie jest skazany na będącą wyzwaniem dla jego natury wieczną walkę z samym sobą. Ruch jest według definicji Schillera taką cechą podmiotu, którą można wyodrębnić, nic nie zmieniając w naturze tego ostatniego. Człowiek wykonuje ruchy samowolne (willkürlich), które nie wynikają wyłącznie z praw natury, lecz są przejawem samo-woli, dowodem istnienia wolności podmiotu, nie podlegają zatem konieczności, ale są jego „osobistą zasługą”. Ruchy wynikające $\mathrm{z}$ własnej woli mogą być oczywiście rezultatem uczuć moralnych i mogą być zamierzone, natomiast takie ruchy samowolne, które nie wynikają z woli i następują bez jej udziału, czyli ruchy mimowolne (unwillkürlich), to czysty wdzięk. Ruch samowolny, jeśli nie towarzyszy mu ruch mimowolny, nie może odznaczać się gracją. Ruch samowolny jest następstwem działania umysłu, jest rezultatem jakiegoś „zastanowienia”, które w chwili wykonywania ruchu należy już do przeszłości. Ruch mimowolny natomiast - efekt natury - towarzyszy czynności umysłu w chwili jego wykonania, będąc zarazem objawem stanu uczuciowego podmiotu.

Kiedy wyciągam rękę - pisze Schiller - aby odebrać od kogoś jakiś przedmiot, realizuję pewien cel, a ruch, jaki wykonuję, podyktowany jest zamiarem, który pragnę przy tym spełnić. Jednakże $\mathrm{w}$ danej chwili nie określam dokładnie, w jaki sposób wezmę podawany mi przedmiot, czy zwrócę się do podającego także całym ciałem, czy zrobię to szybko, czy powoli, i ile siły włożę w wykonanie swego ruchu; pozostanie tu więc coś, o czym decydować będzie moja natura. To jednak, czego nie określa sam cel, wymaga rozstrzygnięcia; decydujące znaczenie więc może mieć tu mój sposób odczuwania, a ton, jaki on nadaje, może określić sposób wykonania ruchu. Otóż udział, jaki w samowolnym ruchu ma uczuciowy stan osoby wykonującej ten ruch, jest mimowolnym składnikiem tego ruchu i w nim to należy doszukiwać się gracji15.

\footnotetext{
${ }^{14}$ F. Schiller, $O$ wdzięku i godności, [w:] tenże, Pisma teoretyczne, s. 240.

${ }^{15}$ Tamże, s. 226.
} 
Wdzięk jest przejawem duchowego stanu osoby wykonującej ruch i każda przemiana zachodząca $\mathrm{w}$ świecie duchowym może objawić się $\mathrm{w}$ świecie zmysłowym tylko jako ruch. Ruchy mimowolne, będące jakby wrodzonym darem natury i jednocześnie wyrazem ducha ludzkiego, są takimi, gdzie wola nie dokonuje przemocy wobec natury, ich podstawową cechą jest lekkość, nie wysiłek. Zmysłowość i rozumność zgodnie w nich współdziałają, a wyrazem tego współdziałania jest zmysłowo postrzegana gracja, za którą leży przyczyna moralna. „Gracja - pisze Schiller - jest łaską, jaką moralność okazuje zmysłowości”'16. Jak na płaszczyźnie religijnej głosił Luter, tylko przez łaskę (sola gratia) można osiągnąć stan duchowej czystości.

... we wdzięku - przekonuje Schiller - podobnie jak w ogóle w pięknie, rozum widzi spełnienie wymagania, jakie postawił zmysłowości; we wdzięku jedna $\mathrm{z}$ idei rozumu niespodziewanie wychodzi mu naprzeciw w zjawisku. Ta zaskakująca harmonia między przypadkowością natury a koniecznością rozumu budzi w nas uczucie radosnego uznania (zadowolenia), które rozprasza zmysły, ducha jednak ożywia i zajmuje... ${ }^{17}$

Jak wynika z powyższego fragmentu, zmysłowe doświadczenie wdzięku wpływa ożywiająco na nasz stan duchowy, surowe zasady prawa moralnego przestają być tylko literą i zamieniają się w życie. Kleist w swej rozprawce daleki był od zamiaru usprawiedliwiania etyki Kanta. Jednak mimo całkowitej obojętności, jaką stara się deklarować wobec tekstu Schillera, wdzięk w jego koncepcji posiada dokładnie takie samo źródło. Schiller jasno wskazuje: „Gdzie spotykamy wdzięk, tam zasadą poruszającą jest dusza i w niej to tkwi przyczyna piękna ruchu”"18. Jak wiemy, Kleist identycznie identyfikuje stanowiącą o wdzięku zasadę poruszającą z duszą. Czyli obaj poeci są w swych wyjaśnieniach całkowicie zgodni. Wdzięk jest przejawem energii życiowej czerpanej z dziedziny ducha. Energii, w jakiej objawia się i udziela nasze człowieczeństwo. Wyraża się ono w cielesnych ruchach, które jednocześnie dowodzą, że człowiek nie jest samym tylko ciałem. Pomimo zgodności co do źródła wdzięku Kleist próbował odciąć się od Schillera. Ten zdolnością do wdzięku obdarza wyłącznie człowieka, Kleist przeciwnie, człowieka z obszaru wdzięku wyklucza, podstawiając w jego miejsce marionetkę. Spróbujmy zastanowić się, dlaczego?

\footnotetext{
16 Tamże, s. 238. Podstawowym znaczeniem łac. gratia jest łaska.

17 Tamże, s. $264 \mathrm{n}$.

18 Tamże, s. 213.
} 
W ujęciu Schillera wdzięk staje się czynnikiem łączącym zmysłowość i rozumność, zasypując przepaść dzielącą obie te dziedziny, znosi ich antagonizm i jest oznaką pojednania. Schiller konstruuje w ten sposób triadę dającą wyraz pełni człowieczeństwa ${ }^{19}$. Triada jako logiczny schemat myślenia towarzyszy refleksji filozoficznej Zachodu praktycznie od jej początków (por. Platońskie dochodzenie do prawdy w trzech etapach). U Schillera myślenie triadyczne dominuje w najważniejszych pismach estetyczno-antropologicznych, poeta używa go niczym rusztowania do budowy swojej podstawowej idei: człowiek wypędzony z raju niewinności przez rozum, za pomocą tegoż rozumu musi stworzyć dla siebie nowy raj wolności. Teza - antyteza - synteza, typowy schemat racjonalizmu ${ }^{20} \mathrm{i}$ wiary $\mathrm{w}$ postęp, w możliwość wychowania człowieka na istotę rozumną, która świadomie zdąża do celu w postaci państwa wyższej kultury i sprawiedliwości gwarantowanej przez wolność.

W kontekście prezentacji fenomenu wdzięku interesujące może okazać się zestawienie dwóch niewielkich tekstów Schillera i Kleista rozpatrujących historię ludzkości i ideę postępu. W krótkim artykule (inspirowanym przez Kanta) pt. Przyczynek do kwestii pierwszego ludzkiego społeczeństwa według nici przewodniej Mojżeszowego dokumentu historia ludzkości zostaje przez Schillera podzielona - nie może być inaczej - na trzy etapy: naturalną niewinność, rozumność oraz raj poznania i wolności, „gdzie (człowiek - D. P.) prawom moralnym w swym sercu stanie się równie nieodmiennie posłuszny, jak na początku posłuszny był instynktowi”21. Człowiek, zrywając owoc z drzewa poznania, dokonuje według Schillera pierwszego samodzielnego kroku na drodze oderwania się od instynktu i realizacji moralnej wolności lub, używając słów Kanta, wyjścia z zawinionej przez siebie „niedojrzałości”22. Dla Kleista zerwanie owocu z drzewa poznania stało się, jak pamiętamy, czymś przeciwnym - źródłem pomyłek w ludzkim postępowaniu i główną

${ }^{19}$ Pełnia człowieczeństwa zostaje osiągnięta w ideale „pięknej duszy”, gdzie „zmysłowość i rozum, obowiązek i skłonność zachowują [...] harmonię, a gracja jest jej wyrazem w zjawisku”. Tamże, s. 249.

${ }^{20}$ Również Lessing, najwybitniejszy twórca niemieckiego Oświecenia, odwołuje się do „trzech epok” w dziejach świata, por. G. E. Lessing, Wychowanie rodzaju ludzkiego, przeł. H. Kahanowa, [w:] tenże, Dzieła wybrane, t. III, Warszawa 1959, s. 553.

${ }^{21}$ F. Schiller, Przyczynek do kwestii pierwszego ludzkiego społeczeństwa wedtug nici przewodniej Mojżeszowego dokumentu, przeł. T. Kupś, „Studia z Historii Filozofii”, 2013, z. 2(4), s. 20. Schiller przejmuje tu główne idee rozprawki Kanta Przypuszczalny początek ludzkiej historii (1786).

${ }^{22}$ I. Kant, Odpowiedź na pytanie: czym jest Oświecenie, przeł. T. Kupś, [w:] Dzieła zebrane, t. VI, Toruń 2012, s. 47. 
przyczyną jego ułomności. W zaledwie półstronicowym artykule Betrachtungen über den Weltlauf (Rozważania o dziejach świata), opublikowanym także w Berliner Abendblätter w wydaniu z 9 października 1810 roku, czyli tylko dwa miesiące przed Teatrem marionetek, Kleist prezentuje zupełnie odmienną wizję rozwoju kultury i moralności. Porządek postępu i liniowego rozwoju, jaki uznane umysły wprowadzają do biegu historii, pisarz nazywa tu po prostu „dziwacznym”. Jeśli wziąć za przykład chociażby kultury Greków i Rzymian, nieprawdą jest, że człowiek rozwija się ze stanu nieokrzesania i dzikości i stopniowo stara się go ulepszyć na drodze rozumu, tworząc reguły cnoty i moralności, dla których uzmysłowienia uprawia jeszcze sztukę, aby osiągnąć tak najwyższy stopień kultury dobra i piękna. Jest całkiem odwrotnie:

Zarówno dla Greków, jak i Rzymian ... początkiem była epoka heroizmu, która jest bez wątpienia czymś najwyższym, co można osiągnąć. Gdy zabrakło im bohaterów, reprezentujących obywatelską i ludzką cnotę, zaczęli ich poetycko tworzyć, gdy już nie potrafili ich tworzyć, próbowali ustanowić reguły poezji, gdy poczęli gmatwać się w regułach, wyabstrahowali wiedzę o świecie, a gdy z tym skończyli, stali się źli ${ }^{23}$.

Widzimy, że Kleist jednym zdaniem rozbija tu opartą na schemacie triady ideę rozwoju historii oraz postępu moralności ku lepszemu i zastępuje ją ideą regresu, sprowadzając logikę historii do paradoksu.

Logika Kanta z Krytyki czystego rozumu jest konstrukcją bardzo skomplikowaną, która nie została w całości oparta na prostej strukturze triadycznej, choć towarzyszy ona tej budowli, poczynając od trzech członów każdej z kategorii aż do trzech idei transcendentalnych. Jednak nie wolno zapominać, że w jednym z kluczowych fragmentów Krytyki... Kant także zmuszony jest odwołać się do paradoksu. Dotyczy on węzłowego punktu teorii poznania poznania samego siebie. Kant pisze:

W tym miejscu należy wytłumaczyć paradoks, który podczas wykładu formy zmysłu wewnętrznego każdego prawie uderzy. Należy mianowicie wyjaśnić, że

\footnotetext{
${ }^{23} \mathrm{H}$. von Kleist, Betrachtungen über den Weltlauf, w: Werke und Briefe in vier Bänden, Bd. III, s. 461.
} 
ten zmysł nawet nas samych przedstawia świadomości nie takich, jakimi jesteśmy sami w sobie, lecz takich, jakimi się samym sobie jawimy ... ${ }^{24}$

Dzieła Kleista, podobnie jak dzieła Schillera, pozostają pod wpływem Kanta, jednak w przypadku Kleista rzecz ma charakter odmienny. O ile Schiller w pismach estetyczno-antropologicznych próbuje dokonać „korekty” systemu moralności Kanta, Kleist, zgodnie z trybem publikacji Krytyk skoncentrował się najpierw na teorii poznania i wyciągnął konsekwencje radykalne. Nie będzie przesadą twierdzenie, że gdyby nie pojawiły się pisma królewieckiego filozofa, Kleist nie zostałby chyba pisarzem, albo jako pisarz byłby twórcą zupełnie innym ${ }^{25}$. W wyniku lektury Kanta przyszły autor Pantesilei porzucił swój ideał kształcenia oraz marzenia o pracy naukowej, za której cel uważał uzyskanie absolutnej prawdy. Wyciągnął wniosek, że wiedza naukowa nigdy nie dostarczy takiej prawdy ${ }^{26}$, rzeczywistość „sama w sobie” (w tym

${ }^{24}$ I. Kant, Krytyka czystego rozumu, przeł. M. Żelazny, [w:] Dzieła zebrane, t. II, Toruń 2013, s. 215 [B 152/153].

${ }^{25}$ Por. m.in. Richard Samuel, który zauważa, że dzięki filozofii Kanta Kleist „odnalazł swe właściwe powołanie jako dramatopisarz”. R. Samuel, Ludwig Muth. Kleist und Kant. Versuch einer neuen Interpretation. Besprechung, „Euphorion”, 1956, Hf. 50, s. 358.

${ }^{26}$ Dowód na tzw. „kryzys Kantowski” w życiu Kleista stanowić ma słynny list do Wilhelminy von Zenge, ukochanej pisarza, z 22 marca 1801 roku. (Nawiasem mówiąc, panna von Zenge trzy lata później poślubi następcę Kanta na królewieckiej Albertynie, Wilhelma Traugotta Kruga). Kleist pisze w nim o „własnej religii”: „Wierzyłem, że kiedyś po śmierci będziemy się wspinać ze stopnia doskonałości, jaki osiągnęliśmy na tej naszej planecie, na drugi, wyższy i ze skarbca prawd, któreśmy zgromadzili tutaj, również i tam będziemy mogli czerpać. [...] Kształcenie się wydawało mi się jedynym celem moich dążeń, prawda - jedynym bogactwem.” Dalej czytamy: „Niedawno zaznajomiłem się z nową nauką, tak zwaną filozofią Kanta i chciałbym się z Tobą podzielić jedną myślą. [...] Gdyby wszyscy ludzie zamiast oczu mieli zielone szkła, musieliby twierdzić, że przedmioty, na jakie przez nie patrzą, są zielone - i nigdy nie mogliby odróżnić, czy ich oko ukazuje im rzeczy takie, jakimi są, czy też dorzuca coś, co nie przynależy rzeczom, lecz oku. Tak dzieje się z rozumem. Nie możemy rozstrzygnąć, czy to, co zwiemy prawdą, jest nią w istocie, czy też tak się nam tylko wydaje. Jeżeli tak nam się wydaje, wówczas prawda, jaką tu na ziemi gromadzimy, nie istnieje po śmierci i próżne są wszelkie usiłowania, by zdobyć sobie tu jakąś wartość, która by nam towarzyszyła aż poza grób... Ach, Wilhelmino, jeśli ostrze tej myśli nie ugodzi Cię w samo serce, nie śmiej się ze mnie, że czuję się nią najgłębiej w najświętszych swych uczuciach zraniony. Straciłem jedyny, najwyższy mój cel, teraz innego nie mam... Od chwili, gdy to przekonanie, że tutaj nie można znaleźć żadnej prawdy, wkradło się do mej duszy, nie ruszyłem żadnej książki." (H. von Kleist, Listy, wyd. cyt., s. 202/203.) W rzeczywistości rozpacz Kleista, w jaką miała go wprawić lektura Kanta, jest tylko spektaklem odgrywanym przed narzeczoną, aby usprawiedliwić ucieczkę od mieszczańskich obowiązków, przede wszystkim nudnej urzędniczej kariery, jaka w najlepszym 
ludzka dusza) jest niepoznawalna. Kant pokazał, że racjonalna nauka o duszy zbudowana jest z paralogizmów, gdzie może być mowa co najwyżej o transcendentalnym podmiocie myśli równym $\mathrm{x}$, o którym nie możemy utworzyć żadnego pojęcia.

Dyskusja o tym, czy Kleist zrozumiał Kanta właściwie, nie wydaje się w tym kontekście mieć istotnego znaczenia. Jak słusznie zwraca uwagę Ernst Cassirer, Kant w Krytyce czystego rozumu nigdzie nie mówi, że prawda jest niemożliwa ${ }^{27}$. Przeciwnie, dowodząc, jak nauka zbudowana jest $\mathrm{z}$ sądów syntetycznych a priori, zrobił wszystko, by uzasadnić i udowodnić prawdę doświadczenia. Autor Teatru marionetek poszukiwał jednak prawdy antropologicznej, wiedzy o wszystkich aspektach bycia człowiekiem, a taka nauka nie może być w ujęciu Kanta wiedzą wyłącznie spekulatywną, lecz musi być także pragmatyczna.

Utwory Kleista - w przeciwieństwie do pism teoretycznych Schillera mają strukturę dualistyczną, a nie triadyczną. W Krytyce czystego rozumu Kant także prezentuje w pewnym momencie dualistyczną formę myślenia, jego antynomie pogrupowane są $\mathrm{w}$ pary, są w każdym z przypadków tylko dwie, tu synteza nie jest możliwa, mówimy o czymś dla intelektu niepoznawalnym. Podobnie Kleist konstruuje antynomie i nie przedstawia ich rozwiązania. Pomijając milczeniem idee Schillera, nie daje żadnej koncepcji „wychowania estetycznego”, pozostawia czytelnika wobec paradoksu. Najwyższym punktem poznania i jedyną wiedzą, jaką można osiągnąć w kwestii poznania wewnętrznej prawdy człowieka, jest paradoks, samozaprzeczenie i konsternacja, wiedza, która jest niewiedzą.

Niczym innym jak wyrazem paradoksu jest to, że w Teatrze marionetek Kleist wyklucza człowieka ze świata wdzięku. Alternatywą bycia człowiekiem

razie go czekała i podjąć projekt zarabiania na chleb jako pisarz. Rodzice Wilhelminy zażądali, aby jej przyszły mąż podjął stałą pracę (sytuacja materialna Kleista nigdy nie pozwoli na to, aby utrzymywać ewentualną rodzinę). Z kolei we wcześniejszym liście do siostry, Ulryki von Kleist, z 14 sierpnia 1800 r., pisarz prosi ją o przysłanie pracy na temat Kanta, którą u niej zostawił. Trudno przypuszczać, aby nagła rozpacz ogarnęła go dopiero co najmniej rok po napisaniu pracy (która niestety zaginęła) o interesującej go filozofii, i której główne idee zamierzał przeszczepić na grunt francuski (list do Wilhelminy z 13.11.1800 r.).

${ }^{27}$ E. Cassirer, Heinrich von Kleist und die Kantische Philosophie, Berlin 1919, s. 9. Cassirer uważa, że kryzys poznawczy opisywany w liście Kleista (zob. przyp. 26) nie był spowodowany lekturą jakiegokolwiek dzieła Kanta, lecz Powołania człowieka Fichtego. Przykładu widzenia przez zielone szkła nie znajdujemy ani u Kanta, ani u Fichtego, jednak o ile Kant odrzucał subiektywność poznania, w tym odwoływanie się do przykładów kolorów i dźwięków, u Fichtego cały aparat poznawczy „Ja" jest czysto subiektywny. 
jest - jak czytaliśmy wyżej - albo kukła, albo Bóg, albo czysta materia, albo czysta duchowość. Jeśli mamy to rozumieć dosłownie, zarówno kukła jak i Bóg mogą posiadać wdzięk, do czego człowiek z reguły okazuje się niezdolny. Spróbujmy jednak postawić pytanie, czy „zarówno - jak i” nie jest zamierzonym przez Kleista wyznaczeniem dwóch punktów granicznych, pomiędzy którymi znajduje się życie człowieka, rozciągające się właśnie między czystą materią i czystym duchem? Piękny to paradoks, gdy „zarówno - jak i” oznaczać ma „ani - ani”.

Zastanówmy się raz jeszcze nad zagadkowymi fragmentami tekstu Kleista i powróćmy do wątpliwości dotyczących tańca lalkarza. Zadaniem lalkarza jest zapanować nad środkiem ciężkości ruchu marionetki, tak aby jej członki, „będące jedynie wahadłami, mechanicznie” [574] ruszyły za nim. Widać wyraźnie, że jej wdzięk nie jest jednak wdziękiem lalki, która podlega sile ciężkości i bez starań lalkarza spadnie bezwładnie na ziemię. Siła poruszająca ( $v i s$ motrix) lub dusza ruchu marionetki jest wyłącznie dziełem lalkarza, władającego jej środkiem ciężkości „wewnątrz postaci” [574]. Jak stwierdza pan C., praca ta wydaje się od mechanicznej strony stosunkowo nietrudna, ale „nie wynika stąd jeszcze, że można uprawiać ją całkiem bez czucia” [574]. Lalkarz, władając tym środkiem ciężkości, kreśli linie proste lub (będące właściwym źródłem wdzięku) elipsy, elipsa zaś - jak czytamy - „(za sprawą stawów) jest dla końców ludzkiego ciała postacią ruchu wręcz naturalną” [574]. Kleist się tu nie myli, pisząc o ciele ludzkim, natomiast nie można tego powiedzieć o marionetce: jest ona co najwyżej „przedłużeniem” ciała lalkarza. Elipsa precyzuje Kleist - to linia „wielce tajemnicza”, jest ona „ni mniej, ni więcej, tylko drogą duszy tancerza; i wątpliwe, by dała się znaleźć inaczej, niż gdy animator wczuwa się w środek ciężkości marionetki, czyli - innymi słowy gdy tańczy" [575]. Niniejsze zdanie na temat elipsy bezsprzecznie dowodzi, że w ruchu marionetki musi pojawić się czynnik ludzki, bez niego kukiełka to tylko rzecz. Rzecz bez świadomości, woli i rozumu, i nie można traktować jej poważnie jako wzoru dla człowieka, którego problem polega właśnie na tym, że owe własności posiada. W rzeczywistości cała energia marionetki pochodzi od człowieka trzymającego ją na sznurku. Wyobraźmy sobie, tak jak chcieliby obaj uczestnicy dialogu, że animator zostaje zastąpiony przez jakąś maszynę czy korbę, i cały powab marionetki byłby produkcją czysto mechaniczną. Wówczas wrażenie wdzięku momentalnie pryska, dziwoląg taki wprawdzie mógłby wzbudzić chwilowe zainteresowanie obserwatora, podobnie jak wzbudziłoby je dwugłowe cielę czy jakaś gadająca małpa, jednak bez udziału uczucia zachwytu. Piękno i wdzięk kukły są zatem tylko rodzajem 
figury retorycznej, lub - używając języka Kanta - fikcją heurystyczną, czymś pomyślanym „tylko problematycznie”28, podobnie jak Bóg wyposażony w oglądający intelekt. Pomiędzy nimi, lalką i Bogiem, sytuuje się człowiek, o którym Kleist nie chce jednak powiedzieć, że dysponuje taką własnością jak wdzięk. Zamiast tego dowiadujemy się, że elipsa, linia „wielce tajemnicza”, jest „drogą duszy tancerza” - a więc tańczący lalkarz ma duszę, poruszającą się tajemniczymi drogami i zdolną obdarzać wdziękiem martwą marionetkę. Wdzięk w koncepcji Kleista jest momentem wskazującym na tajemnicę, a o tajemnicy zwykle wiemy, że jest, ale nie mamy pojęcia, co zawiera. Linię elipsy da się wprawdzie przedstawić $\mathrm{w}$ równaniach algebraicznych - w języku matematyki, ale ani na krok nie zbliży nas to do poznania wnętrza człowieka, w którym to wnętrzu ma swe źródło ruch, kreślący tak powabny kształt. Elipsa jest także figurą retoryczną polegającą na niedopowiedzeniu, poruszającą u odbiorcy element refleksyjny i pobudzającą do myślenia. Kleist, podobnie jak Schiller, rozumie wdzięk jako objawienie wnętrza, zmysłowość, która jest wyrazem i odwzorowaniem ludzkiego ducha.

O ile celem Schillera jest zapewnienie stabilizacji ideału, Kleist ideał chce zdestabilizować, zapewnia nas o sprzecznościach przy każdej próbie uzyskania pewności. Młodzieniec osuszający stopę, gdy miał „wypróbować pewność wdzięku" [579], już go stracił, wdzięk dostrzegamy w momencie, gdy już znika, jest jak od razu gasnący rozbłysk światła ${ }^{29}$. W opozycji do Schillera, który stara się wdzięk ukazać bliżej i nadać mu charakter moralny, Kleist proponuje wykładnię diametralnie inną. To nie tylko fenomen pozamoralny, ale także pozalogiczny i pozajęzykowy. Trudno byłoby opisać komuś doświadczenie wdzięku. Przedmiotem wiedzy może być tylko to, że wdzięk towarzyszący ruchom człowieka jest - i już nie jest, reszta wymyka się jakiejkolwiek refleksji, stajemy wobec paradoksu.

W dialogu $O$ teatrze marionetek pan C. zostaje określony jako ktoś, kto wywodzi „swe paradoksy” [578]. Zacytowana na wstępie rozprawka O zastanowieniu także nosi podtytuł Paradoks (Eine Paradoxe), co stanowi właściwie paradoks do kwadratu, gdyż Kleist zmienia w tym słowie używany w niemieckim rodzaj nijaki na żeński, chcąc chyba jeszcze bardziej zaintrygować czytelnika.

\footnotetext{
${ }^{28}$ I. Kant, Krytyka czystego rozumu, s. 673 [B 799].

${ }^{29}$ Słuszne wydaje się spostrzeżenie, że gdy moment wdzięku przedłuża się, ruch staje się tylko wdzięczeniem.
} 
Paradoks jako rezultat poznania i formuła wiedzy o człowieku okazuje się dominującą zasadą w twórczości Kleista. W zakończeniu Teatru marionetek jeszcze raz pojawia się odwołanie do „niewinności' człowieka, do braku świadomości nieskażonej poznaniem jako warunku wdzięku. Narrator historii zastanawia się, jak można tę utraconą niewinność odzyskać:

Czyżbyśmy zatem, rzekłem nieco oszołomiony, czyżbyśmy, chcąc na powrót popaść $\mathrm{w}$ stan niewinności, powinni znowu zjeść owoc $\mathrm{z}$ drzewa poznania? Owszem - odpowiada pan C. - to ostatni rozdział w dziejach świata. [581]

Dwa zdania i dwa paradoksy. Aby „znowu zjeść owoc z drzewa poznania” trzeba powrócić do bram raju, czyli - jak mówi Kleist wcześniej - „odbyć podróż dookoła świata i zobaczyć, czy raj gdzieś u tylnego wejścia nie otworzył się na nowo" [577]. Taka podróż nie oznacza oczywiście okrążenia kuli ziemskiej, lecz podróż przez bieg historii. Historia poznania nie jest ciągłą linią prostą prowadząca do określonego celu, lecz porusza się „dookoła”, ruchem kolistym, co wyklucza jakiekolwiek ostateczne i niezmienne rezultaty. To paradoks pierwszy. Następnie czytamy, że taki powrót do raju oznaczałby „ostatni rozdział w dziejach świata”, co stanowi paradoks drugi. Początek poznania okazuje się jednocześnie jego końcem, przypowieść o raju staje się jednocześnie apokalipsą, poznanie (czytaj: refleksja na temat wdzięku) niesie w zarodku własne zniszczenie, jest już u podstaw własną negacją.

Pozwólmy sobie jeszcze przytoczyć przykład obrazujący, w jaki sposób Kleist buduje „swe paradoksy” w dziełach literackich - znakomitą nowelę Markiza O. Już w pierwszym zdaniu dowiadujemy się, że Markiza O., „dama o nieposzlakowanej opinii”, zamieściła w gazetach ogłoszenie, że „bez swej wiedzy znalazła się w odmiennym stanie”, i że „ojciec mającego się narodzić dziecka winien się zgłosić”" ${ }^{30}$. Nawet w dzisiejszych „zepsutych” czasach, gdyby podobne ogłoszenie pojawiło się gdzieś $\mathrm{w}$ prasie czy w internecie, trudno byłoby mówić o nieposzlakowanej opinii, a w noweli mamy rok 1799 - akcja rozgrywa się podczas drugiej Wojny Koalicyjnej przeciw Napoleonowi ${ }^{31}$. Nie mogąc sobie przypomnieć momentu poczęcia i nie dopuszczając myśli o ciąży, O. wezwała lekarza, a potem jeszcze dla pewności doświadczoną akuszerkę. Po skończonym badaniu markiza zapytała ją, czy możliwe jest nieświadome poczęcie. Usłyszała, że „poza Panną Świętą nie zdarzyło się to żad-

${ }^{30}$ H. Kleist, Markiza O., przeł. E. Sicińska, [w:] Dzieła wybrane, Warszawa 1960, s. 505.

${ }^{31}$ Por. S. Doering, Heinrich von Kleist. Die Marquise von O... . Erläuterungen und Dokumente. Stuttgart 2008, s. 9. 
nej kobiecie na ziemi”32. Matka O. na wieść o jej niewyjaśnionej ciąży przeklęła godzinę, w której ją urodziła. Ojciec był jeszcze gorszy. Wyzywał: „Przebiegła obłudnica! Dziesięciokrotny bezwstyd suki sparzony z dziesięciokrotną chytrością lisa jeszcze jej nie dorównują!"33 Skąd ciąża? Otóż w jednej z pierwszych scen noweli dziarscy Rosjanie szturmujący cytadelę przypuścili szturm także na markizę. Uratował ją ich dowódca, oficer rosyjski hrabia F., który w tamtej chwili „Markizie wydawał się aniołem z nieba” ${ }^{34}$. Przemawiając do niej uprzejmie po francusku, zaprowadził ją do innego skrzydła pałacu, gdzie markiza popadła w omdlenie. Jak czytamy: „Tu - "35. I jest to chyba najsłynniejszy myślnik w dziejach literatury. Zapytana później, jak podoba się jej wybawiciel, odpowiedziała: „Podoba mi się i nie podoba” ${ }^{36}$. Hrabia F., wypełniając rozkazy dowództwa, musiał natychmiast opuścić fort, a wkrótce potem do miasta nadeszła wieść o jego śmierci na polu chwały. Jak się okazało, była ona fałszywa, gdyż w odpowiedzi na gazetowy anons markizy O. oficer wrócił uleczony z ciężkich ran, piękny jak „młody bóg” ${ }^{37}$ i poprosił ją o rękę. Trudno było namówić markizę $O{ }^{38}$ na ślub: „Byłam przygotowana na rozpustnika, ale nie na - diabła" ${ }^{39}$.

Jedna tylko myśl była dla niej nie do zniesienia, ta mianowicie, że na istocie, którą poczęła z największą niewinnością i czystością i której pochodzenie właśnie dlatego, że bardziej tajemnicze, zdawało się być także bardziej boskie niż innych ludzi, miało ciążyć piętno hańby ${ }^{40}$.

Ponieważ dziecko musi mieć ojca, ślub jest konieczny. Hrabia F. zrzekł się wszelkich praw małżonka, mimo to wspierał dziecko pokaźnymi sumami. Z czasem zdobył miłość markizy i „przyszło na świat wielu małych Rosjan”41. W ostatniej scenie markiza „rzucając mu się na szyję, wyznała, iż nie byłby

${ }^{32}$ H. Kleist, Markiza O., s. 525.

${ }^{33}$ Tamże, s. 533.

${ }^{34}$ Tamże, s. 506.

${ }^{35}$ Tamże, s. 507.

36 Tamże, s. 518.

${ }^{37}$ Tamże, s. 510.

${ }^{38}$ Sabine Doering zwraca uwagę, że litera „O” jest chrześcijańskim symbolem Marii; w języku hiszpańskim ciężarną Marię, określa się „Maria de la O”. S. Doering, Heinrich von Kleist. Die Marquise von O..., s. 8.

${ }^{39}$ H. Kleist, Markiza O., s. 543.

${ }^{40}$ Tamże, s. 528.

${ }^{41}$ Tamże, s. 546. 
się jej wtedy wydał diabłem, gdyby za pierwszym jego pojawieniem się nie uważała go za anioła"42. Jak widzimy paradoks na paradoksie, tajemnica przykrywa tajemnicę.

Wróćmy do problemu Kleistowskiej recepcji Kanta. Wiemy, że czytał on Krytykę władzy sądzenia, której tytuł zresztą wymienia w Berliner Abendblätter z 2 października 1810 roku. Czytać miał także Krytykę praktycznego rozumu oraz Religię w obrębie samego rozumu. Zagadnienia moralne także niezmiernie go zajmowały. Przykładem może być inna nowela Michael Kohlhaas. Tu kolejny paradoks Kleista: tytułowy bohater, żywiąc głęboki szacunek dla prawa, staje się przestępcą i mordercą. Niektórzy badacze powątpiewają, czy autor Teatru... zdołał przeczytać Krytykę czystego rozumu. Jako dowód służyć ma słownictwo, którym się posługiwał w swej twórczości. Brakować ma w nim fundamentalnych pojęć Kanta, takich jak „rzecz sama w sobie” (Ding an sich) czy też zjawisko (Erscheinung). Dowód to mało przekonywający, tym bardziej, że jeśli chodzi o termin „zjawisko”, jest na pewno inaczej. W samej Markizie O. słowo to występuje w dwóch węzłowych miejscach, co polski przekład nie zawsze oddaje. W rozmowie $\mathrm{z}$ akuszerką, gdy markiza zapytała złamanym głosem, ,jak natura zrządza te rzeczy” ${ }^{43}$ (w oryginale: ob diese Erscheinung im Reiche der Natur sei) oraz w cytowanej już scenie końcowej, gdzie hrabia „nie byłby się jej wtedy wydał diabłem, gdyby za pierwszym jego pojawieniem się nie uważała go za anioła" (er würde ihr damals nicht wie ein Teufel erschienen sein, wenn er ihr nicht, bei seiner ersten Erscheinung wie ein Engel vorgekommen wäre). Erscheinung - zjawisko to według definicji Kanta „nieokreślony przedmiot empirycznego oglądu” ${ }^{4}$. Kleist nie buduje koncepcji poznania śladem Kanta, rezygnuje w ogóle z logicznego określania, od razu dołącza do zjawiska cechy sprzeczne.

Kolejnym istotnym przykładem inspiracji Kleista przez filozofię Kanta jest jego recepcja Krytyki władzy sądzenia w części dotyczącej definicji sztuki. Nie będzie pomyłką powiedzieć, że Kleist jako artysta wciela w życie teorię z $\$ 49$ tej Krytyki zatytułowanego $O$ władzach umysłu składających się na geniusz. Geniusz w definicji Kanta jest twórcą mającym zdolność wydobywania idei estetycznych, będących takim przedstawieniem wyobraźni, „które daje dużo do myślenia, przy czym jednak żadna określona myśl, tzn. pojęcie, nie może być mu adekwatna, a w efekcie żadna mowa nie może go ani w całości ująć,

\footnotetext{
42 Tamże.

${ }^{43}$ Tamże, s. 525.

${ }^{44}$ I. Kant, Krytyka czystego rozumu, s. 122 [B 34].
} 
ani uczynić zrozumiałym"45. Dzieło sztuki - pewna zmaterializowana idea estetyczna - stanowi wyraz ducha ludzkiego ${ }^{46}$, natomiast duch „W znaczeniu estetycznym" jest podstawową zasadą ożywiającą ${ }^{47}$, którą Kleist starał się wyrazić i przekazać w swej twórczości pod postacią paradoksu.

Twórca Teatru marionetek studiował także Antropologię w ujęciu pragmatycznym, późny zapis wykładów królewieckiego filozofa dotyczących człowieka nie jako obiektu teorii poznania, lecz empirycznej obserwacji. Właśnie z Antropologii, z rozdziału O egoizmie, pochodzi fragment, gdzie Kant nawiązuje do problemu paradoksu. Skłonność do tworzenia paradoksów klasyfikuje Kant jako pewną formę egoizmu, „logiczny zmysł prywatny”, polegający na tym, że „ktoś nie chce naśladować innych, lecz pragnie występować jako człowiek wyjątkowy”48. Gdy jednak owa skłonność nie wyrasta „z próżnej chęci wyróżniania się", okazuje się czymś pozytywnym:

Paradoksom przeciwstawia się codzienność, która ma po swojej stronie zwykłe mniemanie. Nie niesie ona wszakże ze sobą więcej pewności niż tamte, a może nawet mniej, ponieważ pozwala zapaść w drzemkę. Natomiast paradoks rozbudza uwagę i badawczość duszy, co nierzadko prowadzi ku jakimś odkryciom ${ }^{49}$.

Na zakończenie przeczytajmy jeszcze wyrazisty fragment napisany przez Novalisa, twórcę i człowieka tylko nieco starszego, jednak bardzo różnego od Kleista. Mimo to urywek ten dobrze oddaje zasadę twórczości autora Teatru marionetek.

Czyżby najwyższa zasada miała za zadanie być także najwyższym paradoksem? Być twierdzeniem, które nie daje nigdy spokoju? Które zawsze przyciąga i odpycha? Ciągle od nowa staje się niezrozumiałe, kiedy tylko już się je zrozumiało? Które nieustannie pobudza naszą aktywność - nigdy jej nie nużąc i nigdy nas do niej nie przyzwyczajając? ${ }^{50}$

${ }^{45}$ Tenże, Krytyka władzy sądzenia, przeł. M. Żelazny, [w:] Dzieła zebrane, t. IV, Toruń 2014, s. 192.

${ }^{46}$ Por. wywód Kanta na początku $₫ 49$, tamże.

${ }^{47}$ Por. tamże.

${ }^{48}$ I. Kant, Antropologia w ujęciu pragmatycznym, przeł. E. Drzazgowska, P. Sosnowska, Warszawa 2005, s. 13.

${ }^{49}$ Tamże.

${ }^{50}$ Novalis, Fragmenty logologiczne (a), nr 9, [w:] Uczniowie z Sais. Proza filozoficzna - studia fragmenty, przeł. J. Prokopiuk, Warszawa 1984, s. 174. 


\section{Bibliografia}

Breuer I. (hrsg.), Kleist-Handbuch. Leben - Werk - Wirkung, Stuttgart-Weimar 2013. Cassirer E., Heinrich von Kleist und die Kantische Philosophie, Berlin 1919.

Doering S., Heinrich von Kleist. Die Marquise von O... . Erläuterungen und Dokumente, Stuttgart 2008.

Grimm J., Grimm W., Deutsches Wörterbuch, http://woerterbuchnetz.de/DWB

Hofmannstahl H. v., Deutsches Lesebuch, [w:] Gesammelte Werke in Einzelausgaben, Prosa IV, Frankfurt a. M. 1955, s. 132-141.

Kant I., Krytyka czystego rozumu, przeł. M. Żelazny, [w:] Dzieła zebrane, t. II, Toruń 2013.

Kant I., Krytyka władzy sądzenia, przeł. M. Żelazny, [w:] Dzieła zabrane, t. IV, Toruń 2014.

Kant I., Odpowiedź na pytanie: Czym jest Oświecenie, przeł. T. Kupś, [w:] Dzieła zebrane, t. VI, Toruń 2012, s. 45-54.

Kant I., Antropologia w ujęciu pragmatycznym, przeł. E. Drzazgowska, P. Sosnowska, Warszawa 2005.

Kleist H. v., Über das Marionettentheater, [w:] Werke und Briefe in vier Bänden, Frankfurt a. M. 1986, Bd. III, s. 473-480.

Kleist H. v., Von der Überlegung. Eine Paradoxe, [w:] Werke und Briefe in vier Bänden, Frankfurt a. M. 1986, Bd. III, s. 471-472.

Kleist H. v., Betrachtungen über den Weltlauf, [w:] Werke und Briefe in vier Bänden, Frankfurt a. M. 1986, Bd. III, s. 460-461.

Kleist H. v., Die Marquise von O..., [w:] Werke und Briefe in vier Bänden, Frankfurt a. M. 1986, Bd. III, s. 113-157.

Kleist H. v., Michael Kohlhaas, [w:] Werke und Briefe in vier Bänden, Frankfurt a. M. 1986, Bd. III, s. 7-112.

Kleist H. v., O teatrze marionetek, przeł. J. Ekier, [w:] Pisma teoretyczne niemieckich romantyków, opr. T. Namowicz, Wrocław-Warszawa-Kraków 2000, s. 571-581.

Kleist H. v., Markiza O., przeł. E. Sicińska, [w:] Dzieła wybrane, Warszawa 1960, s. 505-546.

Kleist H. v., Listy, przeł. W. Markowska, Warszawa 1983.

Knab J., Ästhetik der Anmut. Studien zur „Schönheit der Bewegung“im 18. Jahrhundert, Frankfurt a. M. 1996.

Leibniz W. G., Nowy system..., zarzuty..., uwagi... i odpowiedzi, [w:] tenże, Pisma z metafizyku natury, wybór i red. S. Blandzi, Toruń 1999, s. 17-49.

Lessing G. E., Wychowanie rodzaju ludzkiego, przeł. H. Kahanowa, [w:] Dzieła wybrane, t. III, Warszawa 1959, s. 529-555. 
Müller-Seidel W. v., Die Struktur des Widerspruchs in Kleists „Marquise von O...”, [w:] Heinrich von Kleist. Aufsätze und Essays, (hrsg.) W. Müller-Seidel, Darmstadt 1967, s. 244-268.

Novalis, Fragmenty logologiczne (a), [w:] Uczniowie z Sais. Proza filozoficzna - studia - fragmenty, przeł. J. Prokopiuk, Warszawa 1984, s. 172-183.

Piprek J., Ippoldt J., Wielki słownik niemiecko-polski, t. II, Warszawa 1983.

Samuel R., Ludwig Muth. Kleist und Kant. Versuch einer neuen Interpretation. Besprechung, „Euphorion“, 1956, Hf. 50, s. 358-360.

Schiller F., O wdzięku i godności, przeł. J. Prokopiuk, [w:] tenże, Pisma teoretyczne, Warszawa 2011, s. 209-272.

Schiller F., Kallias, czyli o pięknie, przeł. K. Kaśkiewicz, Kęty 2007, s. 3350/67.

Schiller F., Przyczynek do kwestii pierwszego ludzkiego społeczeństwa według nici przewodniej Mojżeszowego dokumentu, przeł. T. Kupś, „Studia z Historii Filozofii”, 2013, 2(4), s. 19-32.

Stockum T. C. v., Heinrich von Kleist und die Kant-Krise, [w:] Heinrich von Kleist. Aufsätze und Essays, (hrsg.) W. Müller-Seidel, Darmstadt 1967, s. 269-271.

Szeluga A., Zwischen Literatur und Philosophie. Zur Rezeption der Kantischen Werke im Leben und Schaffen Heinrich von Kleists, „Studia Niemcoznawcze”, t. XXV, Warszawa 2003, s. 633-639.

Wiese B. v., Das verlorene und wieder zu findende Paradies. Eine Studie über den Begriff der Anmut bei Goethe, Kleist und Schiller, [w:] Kleists Aufsatz über das Marionettentheater, (hrsg.) H. Sembdner, Berlin 1967, s. 196-220.

\section{Abstract \\ Paradox of Grace. On the Marionette Theatre by Heinrich von Kleist}

The article is an attempt of interpreting On the Marionette Theatre by H. v. Kleist. Kleist as a writer uses the principle of paradox and coincidence in his work. The claim that a marionette possesses more grace than a man is, according to the author of this text, also a paradox consciously applied by Kleist. It mostly concerns the phenomenon of human grace, which is a manifestation of the spiritual state of a person. The author also draws attention to the reception of Kant's philosophy and Schiller's aesthetics, out of which Kleist drew radical conclusions.

Key words: Kleist, Kant, Schiller, marionette, paradox, grace 